\title{
Doctrine as security? A systematic theological critique of the operational theological framework of the controversial South African neo-Pentecostal prophets
}

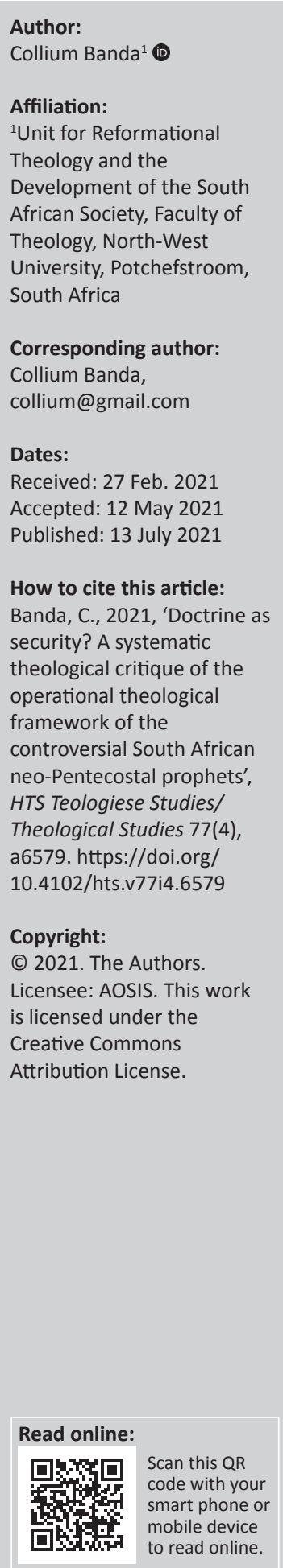

This research article uses the theoretical framework of doctrine as believer's security to critique the theological framework behind the controversial activities reported amongst some South African neo-Pentecostal prophets (NPPs), which include feeding congregants with grass, spraying them with insecticides and sexual violation of women congregants. The framework of the article falls within the discipline of systematic theology by raising the importance for South African Christians to develop a critical doctrinal framework for protecting themselves from controversial NPPs. The following main question is answered by the article: from a systematic theological perspective, how can we evaluate the theological framework, which leads to the recent controversial activities reported amongst some NPPs in South Africa? Consequently, the article, firstly, describes the critical theological framework of the protective role of Christian doctrine. Secondly, it describes the South African NPPs and their controversial practices. Thirdly, this article analyses some of the theological problems in the current operative framework of NPPs. Fourthly, it argues for the need for doctrinally informed critical thinking as a safety measure against controversial NPPs. Finally, some steps that must be taken by NPPs to develop critical theological thinking in order to overcome doctrinally vacuous experientialism that promotes controversial religious activities are provided.

Contribution: From a systematic theological approach, this article attempts to demonstrate the importance of critical doctrinal thinking as a defence mechanism for protecting Christians from falling prey to harmful religious practices, such as those recently reported amongst some NPPs in South Africa.

Keywords: doctrine; South African neo-Pentecostal prophets; critical theological thinking; confession; spiritual experience; security in doctrine; doctrine as security.

\section{Introduction}

The focus of this research article is the operational theological framework that prompts South African neo-Pentecostal prophets (NPPs) to carry out the questionable practices that are widely reported in the media. Previous studies have critiqued these NPPs from various theoretical and theological perspectives, such as the religious nature of their controversial practices (Resane 2017), the view of prophecy (Kgatle 2019), cultism (Kgatle 2021), coloniality (Dube 2019), their view of the church (Banda 2020c; Kgatle 2020a), salvation (Banda 2020b) and the Holy Spirit (Banda 2019a). This article contributes to the growing body of studies on NPPs in South Africa by examining their operational theological framework from a systematic theological perspective, which allows them to carry out the reported controversial practices. The following question is answered by this article: 'from a systematic theological perspective, how can we evaluate the theological framework which leads to the recent controversial activities reported amongst some neo-Pentecostal prophets in South Africa?' By a systematic theological perspective is meant the application of doctrinally informed critical theological reasoning in matters of faith and practice. The application of a systematic theological perspective means that, for example, when a prophet tells a woman that God has told him to sleep with her in order to heal her, doctrinal awareness of God as sovereign and righteous and the biblical demand for sexual purity will make her to reject and condemn such unholy demands incongruent to godly Christian practices. Such theological thinking will enable a woman targeted by the prophet to realise that God in his unlimitedness has many ways of healing and blessing people without the need for unholy acts, such as sexual violation or giving away her material possessions. 
In order to answer the above-stated research question, the following steps are observed: firstly, the critical theological framework of the protective role of Christian doctrine is described. Secondly, the South African NPPs and their controversial practices are briefly described. Thirdly, some theological problems in the current operative framework of NPPs are presented and analysed. Fourthly, an argument is made on the need for doctrinally informed critical thinking as a safety measure against controversial NPPs. This article concludes by presenting some steps that NPPs must take to develop critical theological thinking in order to overcome doctrinally vacuous experientialism that promotes controversial religious activities. Although the article does not attempt to exposit in detail any doctrines, it falls within the field of systematic theology, because it wrestles with the value of doctrinally informed reasoning in Christian life. Although this study concentrates on the neo-prophetic scene in South Africa, it raises issues that have been witnessed across the African continent.

\section{The critical systematic theological framework of the protective role of Christian doctrine}

The theoretical framework used to critique the controversial practices of the NPPs is from a systematic theological perspective that views doctrines as the church's protective mechanism against errors and harmful religious teachings and practices. Some Christians regard doctrines as unnecessary human-made burdens that stand in the way of true spiritual life guided by the Holy Spirit. The critical systematic theological framework challenges believers to consider the protective value of doctrines in ordinary Christian life, as it grounds them on the truth and prevents them from becoming victims of unhealthy spiritual teachings (Eph 4:14-16). Paul shows the protective role of doctrines by warning Timothy that if he watches his doctrine closely, he will save both himself and his followers (Tm 1 4:16).

According to Horton (2011:29), this doctrinal framework falls within the discipline of systematic theology, which puts biblical 'themes together in order to show their logical connections'. He adds that the principle in systematic theology 'is one of logical construction' (Horton 2011:29). Similarly, Grudem (1994:21) added that systematic theology answers the question, '[w] hat does the whole Bible teach us today?' about any given topic. To this extent, good systematic theology uses critical thinking in the gathering and interpreting of relevant biblical passages leading to the construction of doctrinal positions. This is why Grenz and Oslon (1996:39) see the central task of Christian theology as to 'understand and describe what we believe as Christians, what we hold to be true given our faith in Christ'. In theory, the church is as strong and secure as the state of its doctrinal base. Thus, when Christians neglect or refuse to critically and systematically think about their faith, they become vulnerable to false teachings, and their faith remains shallow and are unable to ward off false teachers.
It is argued that the neglect and anathematisation of theological thinking are some of the causes of the controversial religious activities, abuse of religion and congregants, as witnessed in the recent controversial NPPs. This framework recognises that our doctrinal formulations are human acts, resulting from the (De Gruchy 1987):

$[O] f t e n$ agonizing and always fallible human struggle to know who Jesus Christ is for us today in your own situation and, therefore what God requires of us here and now. (p. 58)

Although all doctrines are humanly constructed, their absence robs Christians the protection they need from abusive manipulation by their leaders and of an objective standard by which these leaders can be held accountable for their actions. This critical theological approach will be used to critique the theological logic of the disturbing and distressing activities reported in some NPPs.

\section{The neo-Pentecostal prophets and their controversial practices in South Africa}

As reported in the media, the questionable practices of the NPPs include the open display of sex-related matters in public church worship (Makhoba 2014), making congregants eat snakes (Jamal 2017), spraying them with an insecticide (Jamal 2017), driving a car over congregants (Areff 2016), using rat meat and dog meat for communion (Pijoos 2019), administering to people rat poison (Jamal 2017), fleecing congregants of their money through questionable spiritual promises and dubious miracles, and money laundering (SowetanLive 2019). It also includes serious criminal acts, such as the rape and sexual abuse of young girls and women (Harding 2018; Manona 2021). The list is inexhaustible, and all are underlain by the denominator of 'abuse of people religious systems and commercialisation of religion' (CRL Rights Commission 2017).

Although NPPs belong to the broader Pentecostal tradition that traces its origins from the 1906 Azusa Street Revival, they are remarkably different from the classical conservative Pentecostals. Some scholars (Kgatle 2020a:3; Tsekpoe 2019:284) classify these churches as the new prophetic churches' to indicate their distinction from classical Pentecostalism. Ramantswana (2019:4) said, 'these churches have their own expression of Pentecostalism' to emphasise that they are distinct from classical Pentecostalism. Whilst they have retained the fundamental teachings of Pentecostalism like the baptism in the Holy Spirit and speaking in tongues, Kgatle (2020a:3) said that prophecy is the most significant feature of new prophetic churches and is the source of their growth in South Africa. Prophecy is so significant that even pastors who did not prophesy when they began their ministries began to engage in one-on-one prophetic ministry when they aligned with these types of churches (Kgatle 2020a:3). The peculiarity of NPPs from classical Pentecostalism lies in their practices of one-on-one prophecy, one-on-one deliverance and consultations, 
charging a certain fee from people who seek their services, working out miracles, such as miracle money and miracle babies, the use of superior titles such as Major One and Professor, and in some cases, claim superiority over biblical prophets (Banda 2020a:1; Kgatle 2019; Tsekpoe 2019:284285). This prophetic element has been the main source of many of the problems reported amongst NPPs as it has become a licence for prophets to carry out many controversial activities. Although Kgatle's (2021:8) study on the cultic nature of the NPPs warns against totally dismissing them as not Christian and even not Pentecostal, it cannot be denied that their theological framework that permits their controversial activities is in conflict with some major Christian doctrines and ethical conduct.

Whilst the prophetic element is not new in African Christianity having been the backbone of many African Independent Churches (AICs) who broke away from mission churches in early 1900s (Tsekpoe 2019:284), NPPs have modernised and sophisticated it to make it appealing to modern sophisticated people. Unlike the old AIC prophets who generally emerged as social misfits and established their shrines in open spaces, in wild bushes, or in secluded hills, NPPs exude an aura of modern urbanity by prominent use of modern technology, English language in their sermons, adopting the latest fashion trends in dress and vehicles, and operate in modernised structures, such as tents or rented modern buildings and even hotels, and whilst some have constructed their own worship centres (Kgatle 2020a:4).

The controversial nature of the neo-Pentecostal prophetic practices is demonstrated by the wide range of the attention they have attracted in South Africa having received criticism from the state president, Cyril Ramaphosa (Shange \& Gous 2019) and the Commission for the Promotion and Protection of the Rights of Cultural, Religious and Linguistic Communities (CRL Rights Commission 2017; Kibuuka, Van Aardt \& Tustin 2016). Some NPPs have been arrested and brought before public courts for various allegations of abusing their prophetic authority over their congregants. Prominent examples include the ongoing high-profile court cases at the Port Elizabeth High Court of Nigerian-born pastor, Timothy Omotoso, the leader of the Jesus Dominion International church and two-accused women accomplices for 97 charges of rape, human trafficking and racketeering, with 47 witnesses testifying against them (Manona 2021), ${ }_{1}$ and Shepherd Bushiri, who is facing charges for fraud, money laundering (Mitchley 2021) and allegations of rape (McCain 2021). Although the law is taking its course in addressing these reported allegations of prophetic misconduct, the troubling concern is that had the congregants, or at least some senior leaders, in NPP churches applied a critical systematic theological framework, some of these unfortunate events may have been avoided or addressed in the early stages of their manifestation before affecting many defenceless victims. Thus, a worrisome concern is the absence of a theological framework that protects congregants from being victims of religious abuse and commercialisation of the religion. It was this lack of a protective mechanism that led the Commission for the Promotion and Protection of the Rights of Cultural, Religious and Linguistic Communities (CRL Rights Commission), an independent state body overseeing religious, cultural and linguistic issues, to recommend the strict regulation of religion in South Africa (CRL Rights Commission 2017).

\section{Some theological problems in the operational framework of the controversial practices of neo- Pentecostal prophets}

This section describes some theological problems in the operational framework of controversial South African NPPs that seems to provide an opportunity for the questionable activities reported among them.

\section{A disregard of the historical doctrines of the church}

A notable problem reported amongst the controversial NPPs is the absence of a fixed central doctrinal structure constructed through rigorous theological processes to uphold and guide beliefs and practices (Kgatle \& Mofokeng 2019:2). Resane (2017:9-14) described the controversial NPPs as antiinstitutional, anti-intellectual, antinomian and antisacramental with respect to their sworn disregard for historical doctrines of the church. Resane's harsh characterisation of the NPPs points to their serious deviation from the historical doctrines of the church, leading to a Christian faith that is doctrinally bankrupt but full of dramatic 'unnatural practices that are not in line with the established confessional Christian faith' (Resane 2017:6). The confessional element means a recognisable body of beliefs publicly known and openly avowed to by the community that allows informed believers to independently live out their faith without depending on their leader for every detail of their Christian life. This is in opposition to the secret knowledge only known by the prophets and is communicated in bits and pieces to the followers, resulting in their absolute dependence on their prophetic leader. Prophetic churches tend to follow a prophetic ecclesiology that is based on the prophetic activities of the prophet than on Christ's openly confessed lordship and headship over the church.

The disregard for the historical doctrines of the church is demonstrated by preaching that does not really focus on repentance, holiness and sanctification, but focuses on healing, deliverance, attaining material prosperity and extraordinary miracles such as revealing a person's home address or the colour of their car (Kgatle 2020b:2). As one listens to neo-Pentecostal prophetic preaching, there are hardly any extended expositions on God, Jesus Christ, humanity, the church and heaven. Whilst they have much to say about the Holy Spirit and the devil, this is usually related 
to people's sickness and poverty. Furthermore, their view of heaven is a realised eschatology that is more focused on the present earthly existence than a future in heaven (Kgatle 2020a:4).

There is a tendency amongst the NPPs to treat God as an 'impersonal deity' by presenting him as a deity, force or power that can only be accessed through prophets as if he is unable to personally relate with his people and independently bless them without the mediation of prophets (Banda 2019b). In promoting their spiritual supremacy, the prophets undermine the personality of God. The faulty theology of God allows the prophets to emerge as the mediators between God and people and creates a room for prophets to groom and rape young girls under the guise of linking them to God's power and blessings (Agazue 2016). A doctrine of God that upholds God's holiness and righteousness would deter the use of God's name in carrying out such abusive behaviour. Furthermore, although NPPs preach Jesus Christ as Lord, they act in ways that do not submit to him as Lord and Saviour as they seem to either compete with Christ's supremacy (Magezi \& Banda 2017) or complement Christ's inadequacies in the lives of the believers (Banda 2018). Concerning their poor soteriology, Deke (2015) stated:

The idea of salvation is taken from the Christian faith, but is changed. New conditions for salvation are given, such as purchase of anointed products, allegiance, the use of certain sacraments and commitment to the organization. Members are thus obliged to fulfil these claims before they can be sure of salvation. Anointed towels, anointed bangles, anointed grass, anointed rings, anointed portraits of the prophets, talismans, oils and all forms of objects have become a common feature in Pentecostalism and African Christianity. (p. 7)

In short, the controversial NPPs do not have a sound biblical understanding and expression of the doctrine of salvation. These practices hardly reflect salvation based on Christ and his work on the cross. For, if one can receive God's blessing by giving money to the prophet, what emerges is a doctrine of salvation by works where the biblical elements of faith, repentance, confession and baptism (depending on whether one see baptism as a soteriological or ecclesiological rite) are marginalised. The lack of a regard for traditional doctrines of the church leads to a Christian faith that is wholly depended on the machinations of the prophet, which allows the abuse of congregants to thrive without an instrument for theological recourse.

\section{The elevation of the prophets over Christ}

The lack of care for sound doctrines in the controversial NPPs can be linked to a Christian faith that is built on the personal spiritual stature and personal vision of the prophets than on Christ. This is a form of cultism because the entire religious experience is wholly dependent on the person of the prophet than on Christ (Kgatle 2021). A problem with NPPs is the promotion of religion that is centred on the spiritual stature and personal vision of the prophets than on Christ, as evidenced by the increase in 'person-centred pilgrimage' (Ramantswana 2019:5), thus resulting in the booming of religious tourism as people travel afar for personal encounters with the prophets (Kgatle 2019:2, 4). Claiming the title 'men and women of God', the prophets emphasise their proximity to God and their spiritual superiority over other believers in ways that undermine Christ's role and power in the lives of believers (Magezi \& Banda 2017). The prophets are not only respected but also feared as the mouthpieces and representatives of God to be obeyed without questioning by all Christians (Gunda \& Machingura 2013). Ultimately, commitment to the spiritual and visionary stature of the prophets has replaced commitment to doctrinal substance.

Paradoxically, this deep prioritisation of prophecy demonstrates a fundamentalist commitment to the Bible, however at the same time it shows a denial of the full authority of the Bible. On one hand, the NPPs have a fundamentalist view of the Bible, treating it as 'the be-all in terms of deciding what they should do as Christians, if not in their actual daily lives then at least in public discussions' (Gunda \& Machingura 2013:21). They use a fundamentalist view of the Bible to extract the notion of 'men of God' who function as 'descendants of the line of the specially chosen few who stood before God and who shared in God's authority' (Gunda \& Machingura 2013:19). This fundamentalist view of the Bible leads to the active use of biblical examples and injunctions 'to justify and rationalize what to do, how to do it, when to do it and why to do it' (Gunda \& Machingura 2013:19). The controversial prophets sometimes base some of their practices on the Bible in ways that suggests full adherence to it. For example, when Pastor Lesego Daniel made his congregants drink petrol telling them it will turn into pineapple juice, he quoted Luke 1:37 that says nothing is impossible for God to do (Martinez 2014).

However, on the other hand, this prioritisation of the prophets by the NPPs is also a denial of the finality of the Bible in religious matters because they effectively deny the traditional Christian belief that the inspiration of the Bible has ended (Rukwati 2012). Neo-Pentecostal prophets believe that 'God intended to always have a representative or representatives among human beings, hence the choice of a successor for Elijah is not only specific, it is also representative' (Gunda \& Machingura 2013:22). Put differently, NPPs believe that the office of the prophet as God's mouthpiece and representative is continuous at all times (Gunda \& Machingura 2013:22). As Ramantswana (2019) pointed out, the:

$[N]$ eo-prophetic churches have, as a key feature, an emphasis on the divine power that resides in the person: the prophet - the person in whom resides the ability to prophesy, heal, deliver and pronounce blessings. (pp. 4-5)

From this excerpt, we see that the prophets use the Bible to construct their authority as men and women of God but then begin to speak and operate according to new revelation, which is extra-textual and treated as more authentic and authoritative (Resane 2017:13), even when it is against biblical teachings that bar evil conduct, such as adultery and stealing. This theological framework elevates the prophets over Christ. 


\section{The promotion of religion that emphasises experience over critical thinking}

Instead of a faith based on sound doctrines formulated through vigorous biblical and theological processes, NPPs promote a religion based on experientialism. For example, when Lethebo Rabalago sprayed congregants with a household insecticide, he said he had been instructed by the Holy Spirit to do so (DailySun 2019). Spraying people with a poisonous substance defies all logic and scientific reasoning, and it intentionally creates an aura of an extraordinary experience. The example of experientialism was also demonstrated by Pastor Lesego Daniel who reportedly (Martinez 2014) enticed his congregants to drink petrol by telling them:

'Do you believe in the Father?' Daniel asked the congregation. 'Can you imagine not being able to have a baby and you come here, drink petrol and tomorrow the doctor says, "No more barrenness, you are pregnant because you drank petrol"'. (n.p.)

What can be seen in these controversial activities is the promise of a unique spiritual experience instead of challenging Christians to think theologically about their faith and their situations. An even more serious problem is that the expectation of miracles is not based on God's unlimited power per se but based on the idea that God can do anything no matter how outrageous and irresponsible. This belief is found in prophets who heal people by making them drink toxic substances. The NPPs seem to ignore the fact that Christ refused such an irresponsible display of God's power when tempted by the devil to jump from the pinnacle of the temple (Lk 4:9-12).

It is important, however, to realise that at a general level, the neo-Pentecostal prophetic quest for experience is rooted in classical conservative Pentecostalism. In its classical form, Pentecostalism originally began as a religion of experience and was suspicious of critical reasoning as an enemy of true spirituality. Pentecostals were inspired by the early church of the Apostles that was full of life, and therefore, 'never envisaged to theorise their ecclesiology or the way the church needs to conduct herself with regard to theology' Kgatle (2020b:1). In its original form, Pentecostalism subscribes to what Kgatle and Mofokeng (2019:2) call a 'hermeneutic of experience', which holds the Bible as the word of God that can only be read and understood through the work of the Holy Spirit. Although classical Pentecostalism rightly challenged the deadness in the overly institutionalised and rationalistic tendencies of the mainline traditional churches (Kärkkäinen 2007:6-7), it needs to be recognised that the hermeneutic of experience it promoted has spiralled into the shameful excesses witnessed in the neo-Pentecostal prophetic churches.

It is not true that many people who attend the controversial neo-Pentecostal prophetic churches are simple-minded people who are being taken advantage by sweet-talking religious charlatans. Some are educated and well to do people, and some even hold high offices in the private and public economic sectors. Rather, the problem lies in the quest for experience that defies logical explanations. As noted by Kgatle and Mofokeng (2019:5), '[r]egardless of their social status and educational achievements, Africans seem to have a cultural predisposition towards experientialism'. This leaning towards experientialism makes them susceptible to unconventional practices.

\section{The idea of spiritual liberation not governed by any ethical codes}

Biblically, there is an inseparable link between doctrine and morality (Tt 1:1), which means that systematic theology and theological ethics belong together. Therefore, when controversial NPPs disregard the traditional doctrines of the church, it opens avenues for the abuse of congregants. The disregard for historical church doctrines, the elevation of the prophets of over Christ and the promotion of experientialism over critical thinking lead to the perception of spiritual freedom that is not governed by biblical moral codes. Neo-Pentecostal prophets show a disconnect between theology and ethics, in that the prophets preach about God, and yet, their religious activities break God's moral laws. It is as if believers transcend into an amoral spiritual realm where anything is possible and can be carried out through God's power (Resane 2017:12). The controversial NPPs 'generally believe that the laws of the land can be capriciously ungodly and, therefore, if not disregarded, should be disobeyed' (Resane 2017:12). The serious problem with this attitude is when it extends to God's moral laws as reflected by numerous incidents of prophets who commit sexual and financial crimes using God's name. The notion of a spiritual liberation from moral codes can also be seen in the use of dog meat for communion (Marupeng 2019), healing methods that involve openly touching women's private parts, the waving of underwear in worship and the open display of sex in public worship (Jacaranda 2016; Weber 2014).

Furthermore, the reported unusual events show a religion that suspends the laws of science by performing dangerous things, such as consuming toxic substances. Thus, it can also be said that some congregants endure being subjected to all these abusive activities by their prophets because they believe that, regardless of their unwholesome nature, these activities are carried out by the 'the man of God', and will, therefore, still heal and bless them. Furthermore, as has been reported in several news reports, many congregants yield to the undesirable treatment from their prophets out of fear because the prophet would have told them that bad things will happen if they refuse to do as the man of God has directed (Agazue 2016). As Resane (2017:13) points out, the NPPs 'tend to disregard the lawful procedures, since they claim or base their action on extra-biblical revelations. All their unlawful practices are connected and legitimised by God'. A critical understanding of basic Christian doctrines, such as salvation by grace, God's sovereignty, goodness and holiness, the authority of Scripture, the holiness of sex would empower informed Christians to reject ungodly and wrong practices, 
such as sexual violation of women and paying prophets in order to be blessed by God. When critical thinking on doctrinal issues is neglected or wilfully suppressed, there is a loss of the mechanisms of upholding human dignity and ethical morality in ministry.

This section attempted to show that it is possible for people claiming to be Christian to carry out ungodly things in the name of Christ when, amongst other things, religious life is no longer informed by critical theological thinking but is informed by experientialism that has no sound biblical and theological basis.

\section{The need for doctrinally informed critical thinking as a safety measure against controversial neo- Pentecostal prophets}

There is a need for Christians in South Africa to protect themselves from the controversial NPPs by developing critical theological thinking informed by sound biblical doctrines.

\section{Defining critical theological thinking}

Critical thinking is the use of cognitive rational analytical skills for understanding reality. Biblically informed critical thinking is a necessary tool for addressing the controversial activities of the neo-Pentecostal prophetic churches. When used appropriately, critical theological thinking is not an enemy of faith but an important ally, which can make faith substantive and meaningful. According to van den Berg (2005:2), critical thinking is 'question[ing] the world and ... engag[ing] critically with the possibilities and alternatives that the world offers'. This involves the use of our rational analytical skills in understanding reality and decisionmaking. A major component of critical thinking is thinking of ourselves and seeking to rationally make sense of the world by ourselves. People who think critically think independently and make their own decisions after considering all the facts available on the matter instead of making a decision based on unsubstantiated threats, fears or empty promises. Van den Berg (2005) added:

When we follow the instructions of others thoughtlessly, accept the authority of others without question, or take things for granted, we are not thinking critically. To reason critically is to think for yourself by challenging authority and critically examining dogma, that is, unquestioned knowledge claims. (p. 2)

Critical thinking essentially means that people do not blindly submit to religious teachings without understanding and rationally analysing them for themselves.

From a systematic theological perspective, it can be stated that critical thinking is analytical reasoning informed by the teachings of Scripture, which function as the authoritative source for all Christian doctrine and living (Tm 2 3:15-16). As Scripture is a product of the Holy Spirit, it can be said that Christian critical reflection on faith is a spiritual exercise. Christian critical thinking requires a hermeneutical system that allows believers to read and apply Scripture in an analytical manner and not a simplistic biblicism that does not follow the basic rules of interpretation.

It must also be noted that critical theological thinking does not mean that believers will necessarily agree on all theological points or that their reached theological position will be the correct one. However, critical theological thinking means that a theological or doctrinal position will be arrived at carefully using a systematic method, which follows a rigorous study and interpretation of biblical texts. This means that in cases of disagreement or when a change is needed, we will be able to see how the position was reached and what makes it different from the other positions held by other believers and what must be carried out to change the theological position.

\section{Critical theological thinking as a spiritual discipline}

There is a tendency amongst Christians to view critical theological thinking as an enemy of true faith. For example, according to Tienou (1990:12), many evangelical Christians avoid critical theology by claiming to 'have no theology but that which is revealed in the Bible'. The fear of critical theology is not just amongst ordinary believers but as De Gruchy (1987:42) pointed out even some ordained clergy in historical conservative churches regard theology as 'something detrimental to their calling and the life and mission of the church'. This shows that neo-Pentecostals are not alone in their aversion of critical theological thinking. Scholars Wells (1993) and Noll (1994) have raised alarm over the problem of the neglect of critical theological thinking in the conservative North-American Evangelical movement. Wells (1993:95) decries that in the Evangelical movement, there is 'disappearance of theology from the life of the Church'. He adds that the disappearance of theology amongst evangelicals can be seen:

$[I] \mathrm{n}$ the vacuous worship that is so prevalent, for example, in the shift from God to the self as the central focus of faith, in the psychological preaching that follows this shift, in the erosion of its conviction, in its strident pragmatism, in its inability to think incisively about the culture, in its reveling in the irrational (sic). (p. 95)

From this point, Wells shows that although the problem of lack of theological thinking may be serious amongst some controversial NPPs, it is also a serious problem within the broader modern Christianity. In fact, it can be said that in the other streams of Christianity, the lack of critical theological thinking presents itself in other set of problems. For example, an analysis of contemporary church worship shows a tendency towards emotionalism and preaching that is more motivational and psychological in its nature, leading to an inward focused spirituality instead of being God centred. This point does not mean that emotions are anti-biblical but that due balance must be made. 
Critical theological thinking is a biblically demanded spiritual act. God expects Christians to think critically about him and his ways. For example, when Isaiah asks, '[t]o whom then will you liken God?' or '[w] hat likeness will you compare with him?' (Is 40:18), he expects an answer from a God worshipper who has accurately and critically grasped God's greatness and uniqueness in relation to other contenders to deity. In the New Testament, the example of Christians who exercised critical theological thinking include the Christians of Berea (Ac 17:10-14) who are praised for their critical attitude towards the gospel received from the apostle Paul. The Bereans received Paul's teachings with a questioning mind informed by the Scriptures, as they turned to them to verify Paul's new teachings. An important dimension is how their prior knowledge functioned as security from being misled. They used their previous knowledge to judge and receive the new teachings from Paul.

Furthermore, it is important to note that God commands Christians to love him with not only their heart, soul and their strength but also with their mind (Mk 12:30). This shows that loving God is not only an emotional thing but also relational and rational matter. Furthermore, Christians are commanded to renew their minds ( $R$ m 12:2), to not be deceived with empty words (Eph 5:6), to not be foolish but wisely understand what the Lord's will is (Eph 5:17), to test everything (Th 1 5:21) and to not believe every spirit but to test the spirits to see whether they are from God (Jn 1 4:1). A detailed exegetical study of these biblical texts and similar verses shows that critical thinking is an essential part of spiritual discernment. These verses show that loving God not only is an emotional exercise but also involves the mental struggle of understanding and applying God's truth to our different living contexts.

Noll (1994:46) rightly pointed out that the gospel of Jesus Christ is holistic and calls the whole person because it is dangerous when parts of the body, such as piety and the mind, meant to complement each other compete against each other. Critical theological reflection is, therefore, necessary to ensure that our piety is informed by the truth of Scripture and not merely emotional experientialism.

\section{Critical theological thinking in defending Christians against the dangerous practices of neo-Pentecostal prophets}

Critical theological thinking is a holy act by which we attempt to grasp God's will for our lives. In addition, it is a necessary defence mechanism, which all Christians must undertake especially when faced with the onslaught of not only heretic teachings but also humanly dangerous practices, such as those reported amongst some NPPs. Critical theological thinking functions as a defence mechanism through which Christians strengthen their grasp of God's revelation and expectation to them. Vanhoozer (1991:100), referring to the biblical exhortation to the believers to 'grow' in their faith, said such maturity of faith pertains not only to intensity of conviction but also to a more developed comprehension of faith's subject matter. Critical theological thinking is important because it functions as a defence mechanism from deception and false teachings. It also functions as mechanism for protecting the church from errors and dangerous simplicity of faith.

Against the onslaught of the controversial NPPs, critical theological thinking prevents the privatisation and commodification of religion by the prophets. Privatisation and commodification mean turning religion into a utilitarian tool to accomplish one's selfish desires, and that God's truth is only known by the prophets. One of the concerns raised by the CRL Rights Commission (2017:33) after its hearings on the commercialisation of religion and abuse of people's religious belief systems is that the lack of peer-review mechanisms amongst South African churches 'has led to some people in the [religious] sector doing whatever they like with no accountability to anyone'. According to the Commission, had there been a peer-review mechanism no one would order people to undertake the above-mentioned questionable religious practices (CRL Rights Commission 2017:33). Although the Commission has in mind a peerreview mechanism where church leaders are held accountable by fellow church leaders for their ministerial actions, Christians who develop doctrinally informed critical skills have the capacity to hold their own leaders accountable for how they lead them. The biblical requirements, as seen above, calling Christians to be alert and avoid being deceived are primarily concerned with alertness to leaders who teach false doctrines (Tm 1 4:1-6).

Indeed, it is a biblical requirement that churches have leaders and teachers (Eph 4:11-14), yet without their own critical theological thinking on doctrines, believers are deprived of religious independence because they must constantly rely on their leaders for religious guidance. Critical theological thinking is a security measure, which protects against commodification of the gospel by deceptive leaders who use their spiritual authority to abuse believers as seen by the controversial NPPs. Critical theological thinking also challenges the sacralisation of leaders and their absolutisation as too spiritual that they are beyond questioning by empowering followers to know the truth, evaluate their belief system and ask the critical questions from their leaders. Critical theological thinking is, therefore, an important security measure against spiritual abuse by controversial NPPs.

\section{Towards developing critical theological thinking in an era of neo-Pentecostal prophetic experientialism}

From a systematic theological perspective, what should NPPs do in order to develop critical theological thinking, which can, in turn, lead to the halting of controversial activities that are harmful to people and damage the reputation of sound religion? Wells (1993:97-100) provided three elements that should form Christian theological 
thought, namely: (1) a confessional element, (2) reflection on this confession, and (3) cultivation of virtues informed and shaped by the confessional element and reflection on it. His points showed that critical theological reflection is not an enemy of faith but a means for stronger faith. Using Wells' points we can develop three steps that can assist Christians to think theologically about their faith in order to protect themselves from falling prey to the controversial NPPs.

\section{Recognition of the importance of the confessional element of our faith}

A foundational problem in the controversial NPPs is theologically baseless experientialism that cannot pass the scrutiny of sound biblical hermeneutics. Therefore, instead of religion based on dramatic experientialism, NPPs must be challenged towards a religion driven by sound doctrines informed by the whole counsel of scripture and extracted through sound hermeneutical principles. Wells (1993:99) pointed out that Christian theology has a 'confessional element', which constitutes 'what the Church believes' and is 'what crystallizes into doctrine'. In other words, authentic Christian faith has a cognitive element, which is the biblically derived factual elements that are foundational to the essence of the faith. This point emphasises the importance of doctrinal content and challenges the neo-Pentecostal tendency to value experience over objective truths. This means that NPPs must be challenged to realise that to be a Christian is not to submit to theologically baseless prophetic experience, however, unique and miraculous they may be. Rather, to be Christian is to believe a body of objective facts that are foundational to the reality of Christianity. The writers of New Testament affirm the importance of doctrine and warn that without doctrine, Christians are in danger, not only of a shallow knowledge of God leading to a shallow faith but that without sound doctrines Christians are in danger of deception by false teachers (Tm $14: 6,16)$.

Critical theological thinking about the confessional element of the church is one of the catalysts that led to the breakaway of the Protestant Reformation from the Roman Catholic Church. Thus, according to Wells (1993):

[C]hurches with roots in the Protestant Reformation confess the truth that God has given to the Church through the inspired Word of God. There may be disagreement about what the Bible teaches on any one subject, as well as how that teaching should be assembled, but there is unanimous agreement that this authoritative truth lies at the heart of Christian life and practice, for this is what it means to live under the authority of Scripture. (p. 99)

This excerpt emphasises the public nature of God's revelation that was openly communicated to all people to understand and order their lives around. The public nature of God's revelation makes the confessional element of the church open, not secretive as neo-Pentecostal prophetic churches.

The open nature of God's revelation challenges the tendency of controversial NPPs to commodify and privatise God's revelation by their hierarchical structure through which charismatic leaders monopolise all the answers and only give selected information to chosen people (Frahm-Arp 2019:8). In this cultic-hierarchical scheme, the open message of the Bible accessible to all ordinary people is undermined by prophets' claims that God has secretly revealed to them more authoritative knowledge, which the followers must obey without questioning them (Rukwati 2012). This elevation of private prophecies over the open words of the Bible destroys the followers' power to question the prophets and leads to their subjection to harmful and humiliating practices. Affirming the protective role of doctrine in the church, Wells (1993) said:

It is this core of confession that the Church's identity is preserved across the ages. This is the watchword by which it is known. Without this knowledge, it is bereft of what defines the Church as the people of God, bereft of the means of belief, worship, sustenance, proclamation, and service. Confession must be at the center (sic.) of every theology that wants to be seen as theologia, the knowledge of God, a knowledge given in and for the people of God. (p. 99)

In other words, authentic Christian faith is not empty experientialism in the name of Christ. Rather, it has substantive biblical facts, which are publicly known, defined, and protected against being corrupted and abused by evil leaders. In this regard, the controversial NPPs are challenged to give top priority to the content of their confessional substance. Here, the controversial NPPs must ask themselves the following questions: what is the theological basis of our faith? What do we believe about God, Jesus Christ, the Holy Spirit, the church, humanity, sin, and the whole array of religious and social issues? They must further ask themselves other following questions: how do we derive our beliefs? How do we read and interpret the Bible to formulate our confessional elements? And how do we relate to the beliefs of the historical Christian community and other Christians around us in our times?

\section{Emphasis on the importance of critical reflection on doctrine}

Neo-Pentecostal prophets should be challenged to not reduce religion to mere dramatic experientialism but emphasise the importance of critical reflection on the confessed elements of the Christian faith. According to Wells (1993:99-100), reflection as a second element of theology 'involves intellectual struggle to understand what it means to be the recipient of God's Word in this present world'. From a systematic theological perspective, the struggle to intellectually evaluate the authenticity of our theological conclusions is a significant effort made to ensure that our doctrinal systems are not arbitrary but are reasonably formulated and articulated. This intellectual struggle involves three important aspects: firstly, paying attention to God's entire self-disclosure in all the scriptures; secondly, a consideration of how other believers in the history of the church have engaged and applied this self-disclosure in their lives; and thirdly, paying attention to the authoritative 
systems of the world, which pose a challenge to the confessed doctrines of the church (Wells 1993:100). The purpose of this act is to ascertain whether our beliefs are scripturally coherent, authentic, God-honouring and human edifying. The Christians' willingness to participate in the mentioned unusual activities in order to demonstrate their faith and to be healed are all signs of a lack of critical reflection on one's faith. A serious failure includes asking the following question: what kind of a Christian God would command a prophet to have a sexual intercourse with a woman in order to drive out of her spiritual curses? How can Christ want his holy sacrifice on the cross to be observed by socially unacceptable practices such as eating dog meat? Therefore, it is important for Christians to ask, 'Are we sure we have grasped that as we ought to have?' (Hill, Knitter \& Madges 1997:289). Furthermore, critical reflection on our religious beliefs 'is a natural consequence of mature faith' and is an essential 'part of the natural process of growing out of child-like faith into adult faith to ask questions about the meaning, truth and relevance of one's religious tradition' (Hill et al. 1997:290).

\section{Emphasis on the ethical consequences of our theological confessions}

Instead of thriving on unusual dramatic religious experientialism, NPPs should be challenged to realise that sound religious faith is ethical. This means that purportedly Christian experiences should not just be judged on their extraordinary and miraculous nature but also on their ethical nature. Whilst Pastor Motsoeneng's healing ritual of telling women to wave their underwear and place their hands on their private parts in church and Pastor Njohi's ordering of women to come to church without underwear may achieve the desired results, such actions fail the ethical test of being actions from a holy God. Those questionable activities do not uphold or promote God's holy and righteous purposes.

\section{According to Wells (1993), theology:}

$[I]$ nvolves the cultivation of those virtues that constitute a wisdom for life, the kind of wisdom in which Christian practice is built on the pillars of confession and surrounded by the scaffolding of reflection. (p. 100)

Essentially, this is 'spirituality that is centrally moral in its nature because God is centrally holy in his being' (Wells 1993:100). A Christian action informed by God's holiness 'sees Christian practice not primarily as a matter of technique but as a matter of truth, and ... refuses to disjoin practice from thought or thought from practice' (Wells 1993:100).

\section{Conclusion}

This research article has attempted to emphasise that critical theological thinking can assist in addressing the theological framework of the NPPs, which allows them to engage in controversial religious activities harmful to their followers and put Christianity into disrepute. This article attempted to answer the following question: from a systematic theological perspective, what can be said about the theological framework that leads to the recent controversial activities reported amongst some NPP churches? Using the theological critical framework of Christian doctrine as a protective measure, the article argued that a driving force in the controversial NPP churches is the absence of analytical doctrines, which promotes a pre-occupation with empty experientialism. The absence of a sound biblically informed doctrinal framework leaves NPP Christians without a framework for questioning the unconventional activities of their prophets. Furthermore, this leaves them without security from spiritual abuse from their prophets. The article suggested that the NPP churches should be challenged to replace their biblically baseless experientialism with critical theological thinking informed by the whole counsel of Scripture. Another following question may arise: who should challenge NPP prophets and their followers to pay serious attention to critical doctrinal thinking? The answer to this question is that this task should be performed by all Christians, particularly trained theologians, concerned with the harm caused by controversial NPP practices and the lack of critical doctrinal thinking. Neo-Pentecostal prophetic churches should be challenged to realise the protective power in critical Christian doctrine. Neo-Pentecostal prophets should be challenged to consider Wells' (1993:97100) call for the prioritisation of the confessional element, reflection on this confession, and the cultivation of virtues informed and shaped by the confessional element and the reflection on it.

\section{Acknowledgements}

The author would like to thank Dr Michael Burgess and Dr Tendesayi Kufa-Chakezha for reading the final draft of the manuscript and assisting with helpful comments for improvement.

\section{Competing interests}

The author declares that he has no financial or personal relationships that may have inappropriately influenced him in writing this article.

\section{Author's contributions}

C.B. is the sole author of this research article.

\section{Ethical considerations}

This article followed all ethical standards for research without direct contact with any human or animal subjects.

\section{Funding information}

This research received no specific grant from any funding agency in the public, commercial or not-for-profit sectors.

\section{Data availability}

Data sharing is not applicable to this article as no new data were created or analysed in this study. 


\section{Disclaimer}

The views and opinions expressed in this article are those of the author and do not necessarily reflect the official policy or position of any affiliated agency of the author.

\section{References}

Agazue, C., 2016, "'He told me that my waist and private parts have been ravaged by demons:" Sexual exploitation of female church members by prophets in Nigeria, Dignity: A Journal on Sexual Exploitation and Violence 1(1), 1-18. https://doi. org/10.23860/dignity.2016.01.01.10

Areff, A., 2016, Snake pastor 'shows power' by driving over 2 congregants, viewed 24 January 2020, from https://www.news24.com/SouthAfrica/News/snakepastor-shows-power-by-driving-over-2-congregants-20160608.

Banda, C., 2018, 'Complementing Christ? A soteriological evaluation of the anointed objects of the African Pentecostal prophets', Conspectus (Special Edition, December), 55-69.

Banda, C., 2019a, 'Managing an elusive force? The holy spirit and the anointed articles of Pentecostal prophets in traditional religious Africa', Verbum et Ecclesia 40(1), a2025. https://doi.org/10.4102/ve.v40i1.2025

Banda, C., 2019b, 'The impersonalisation of God? A theological analysis of the expression of the power of God's kingdom among Zimbabwean Pentecostal prophets', In die Skriflig 53(1), a2395. https://doi.org/10.4102/ids.v53i1.2395

Banda, C., 2020a, 'Mediating God's relationality? A trinitarian perichoretic critique of the reliance on anointed objects in African neo-Pentecostalism', HTS Teologies Studies/Theological Studies 76(1), a5856. https://doi.org/10.4102/hts.v76i1.5856

Banda, C., 2020b, 'Regenerated without being recreated? A soteriological analysis of the African neo-Pentecostal teaching on generational curses', HTS Teologiese Studies/Theological Studies 76(3), a5941. https://doi.org/10.4102/hts.v76i3.5941

Banda, C., 2020c, 'Unsafe spaces? An ecclesiological evaluation and response to recent controversial practices in some South African neo-Pentecostal churches', Verbum et Ecclesia 41(1), a2108. https://doi.org/10.4102/ve.v41i1.2108

CRL Rights Commission, 2017, Report on the hearings on the commercialisation of religion and abuse of people's beliefs systems, viewed 19 October 2020, from https://pmg.org.za/page/CRL\%20Rights?via=homepage-feature-card.

DailySun, 2019, 5 times pastors went too far!, viewed 04 June 2019, from https:// www.dailysun.co.za/News/National/5-times-pastors-went-too-far-20190226.

De Gruchy, J.W., 1987, Theology and ministry in context and crisis: A South African perspective, Collins, London.

Deke, A., 2015, 'The politics of prophets and profits in African Christianity', Politics $12(1), 11-24$

Dube, B., 2019, 'Trajectories of mutual zombification in the praxis of post-colonial faith in South Africa: A need for African decoloniality theology', Acta Theologica 39(1), 55-73. https://doi.org/10.18820/23099089/actat.v39i1.3

Frahm-Arp, M., 2019, 'Why at the start of the Fourth Industrial Revolution do we see a rise in cult-type Pentecostal churches in South Africa?', The Thinker 82(4), 1-9.

Grenz, S.J. \& Olson, R.E., 1996, Who needs theology?: An invitation to the study of God, InterVarsity Press, Downers Grove, IL.

Grudem, W.A., 1994, Systematic theology: An introduction to biblical doctrine, InterVarsity Press, Leicester.

Gunda, M.R. \& Machingura, F., 2013, 'The "Man of God": Understanding biblical influence on contemporary mega-church prophets in Zimbabwe', in E. Chitando, M.R. Gunda \& J. Kügler (eds.), Prophets, profits and the bible in Zimbabwe: Festschrift for Aynos Masotcha Moyo, pp. 15-28, University of Bamberg Press, Bamberg.

Harding, A., 2018, South Africa shocked by live rape trial of Timothy Omotoso, viewed 17 April 2021, from https://www.bbc.com/news/world-africa-45940338.

Hill, B., Knitter, P.F. \& Madges, W., 1997, Faith, religion \& theology: A contemporary introduction, Twenty-Third Publications, Mystic, CT.

Horton, M., 2011, The Christian faith: A systematic theology for pilgrims on the way, Zondervan, Grand Rapids, ML.

Jacaranda, F.M., 2016, Prophet Mboro speaks of healing through blessing underwear viewed 24 March 2020, from https://www.youtube.com/watch?v=49iwlzg1vKg.

Jamal, S., 2017, In pictures: From doom to rattex -5 pastors turning communion wine into noxious substances, viewed 24 January 2020, https://www.timeslive.co.za/ news/south-africa/2017-02-07-in-pictures-from-doom-to-rattex---5-pastorsturning-communion-wine-into-noxious-substances/.

Kärkkäinen, V.-M., 2007, 'Encountering Christ in the full gospel way': An incarnational Pentecostal spirituality', Journal of the European Pentecostal Theological Association 27(1), 5-19. https://doi.org/10.1179/jeb.2007.27.1.002

Kgatle, M.S., 2019, 'Reimagining the practice of Pentecostal prophecy in Southern Africa: A critical engagement', HTS Teologiese Studies/Theological Studies 75(4), a5183. https://doi.org/10.4102/hts.v75i4.5183
Kgatle, M.S., 2020a, 'New paradigms of pneumatological ecclesiology brought about by new prophetic churches within South African Pentecostalism', Verbum et Ecclesia 41(1), a2053. https://doi.org/10.4102/ve.v41i1.2053

Kgatle, M.S., 2020b, 'Towards a balancing act between the emergence of prophetic churches and organisational culture in South African Pentecostalism', Verbum et Ecclesia 41(1), a2118. https://doi.org/10.4102/ve.v41i1.2118

Kgatle, M.S., 2021, Pentecostalism and cultism in South Africa, Palgrave Macmillan, Cham.

Kgatle, M.S. \& Mofokeng, T.R., 2019, 'Towards a decolonial hermeneutic of experience in African Pentecostal Christianity: A South African perspective', HTS Teologiese Studies/Theological Studies 75(4), a5473. https://doi.org/10.4102/ hts.v75i4.5473

Kibuuka, P.K., Van Aardt, C.J. \& Tustin, D.H., 2016, An investigative study of the commercialisation of religion in the Republic of South Africa 2016 Gauteng pilot study, CRL Rights Commission/UNISA, Pretoria.

Magezi, V. \& Banda, C., 2017, 'Competing with Christ? A critical Christological analysis of the reliance on Pentecostal prophets in Zimbabwe', In die Skriflig 51(2), a2273. https://doi.org/10.4102/ids.v51i2.2273

Makhoba, N., 2014, At home with Pastor Mboro, viewed 12 June 2021, from https:// www.news24.com/drum/News/at-home-with-pastor-mboro-20170728

Manona, N., 2021, Timothy Omotoso rape trial: I wanted a father figure, he wanted a girlfriend - Witness, viewed 17 April 2021, from https://www.news24.com/ news24/southafrica/news/timothy-omotoso-rape-trial-i-wanted-a-father-figurehe-wanted-a-girlfriend-witness-20210205.

Martinez, J., 2014, After South African pastor makes church members eat grass, he now forces them to drink petrol, viewed 19 January 2020, from https://www. christianpost com/news/after-south-african-pastor-makes-church-members-eatgrass-he-now-forces-them-to-drink-petrol.html.

Marupeng, P., 2019, Outrage over dog meat 'Communion', viewed 24 January 2020, from https://www.sowetanlive.co.za/news/south-africa/2019-05-23-outrageover-dog-meat-communion/.

McCain, N., 2021, Self-proclaimed prophet Shepherd Bushiri faces rape charges Report, viewed 22 April 2021, from https://www.news24.com/news24/ SouthAfrica/News/self-proclaimed-prophet-shepherd-bushiri-faces-rapecharges-report-20210319.

Mitchley, A., 2021, Bushiri fraud case: Matter postponed as State awaits outcome of extradition hearing, viewed 22 April 2021, from https://www.news24.com/ news24/southafrica/news/bushiri-fraud-case-matter-postponed-as-state-awaitsoutcome-of-extradition-hearing-20210225.

Noll, M., 1994, The scandal of the evangelical mind, W.B. Eerdmans, Grand Rapids, MI.

Pijoos, I., 2019, Polokwane 'pastor' boasts of feeding congregants 'dog meat', viewed 24 January 2020, from https://www.sowetanlive.co.za/news/south-africa/201905-22-polokwane-pastor-boasts-of-feeding-congregants-dog-meat/.

Ramantswana, H., 2019, 'Prophets praying for, or preying on people's faith: A reflection on Prophetic Ministry in the South African context', In die Skriflig 53(4), a2495. https://doi.org/10.4102/ids.v53i4.2495

Resane, K.T., 2017, “'And they shall make you eat grass like oxen” (Daniel 4: 24): Reflections on recent practices in some New Charismatic Churches', Pharos Journal of Theology 98(1), 1-17.

Rukwati, T., 2012, Prophets mustn't be questioned, viewed 17 March 2017, from http://www.herald.co.zw/prophets-mustnt-be-questioned/.

SANews, 2018, Omotoso trial resumes, viewed 17 April 2021, from https://www. sanews.gov.za/south-africa/omotoso-trial-resumes

Shange, N. \& Gous, N., 2019, Pastor Alph Lukau breaks his silence while Cyril Ramaphosa wades in on resurrection, viewed 17 April 2020, from https://www. timeslive.co.za/news/south-africa/2019-02-28-pastor-alph-lukau-breaks-hissilence-while-cyril-ramaphosa-wades-in/.

SowetanLive, 2019, Controversial church leader Shepherd Bushiri arrested, viewed 24 January 2020, from https://www.sowetanlive.co.za/news/south-africa/2019-02 01-controversial-church-leader-shepherd-bushiri-arrested/.

Tienou, T., 1990, The theological task of the church in Africa, Africa Christian Press, Achimota.

Tsekpoe, C., 2019, 'Contemporary prophetic and deliverance ministry challenges in Africa', Transformation 36(4), 280-291. https://doi.org/10.1177/02653788198 66217

Van den Berg, M.E.S., 2005, Critical reasoning and the art of argumentation, University of South Africa, Pretoria.

Vanhoozer, J.K., 1991, 'Christ and Concept: doing Theology and the "ministry" of Philosophy', in J.D. Woodbridge \& T.E. McComskey (eds.), Doing theology in today's world: essays in honor of Kenneth S. Kantzer, pp. 99-146, Zondervan, Grands Rapids, MI.

Weber, K., 2014, Kenyan pastor bans female congregants from wearing underwear in church, viewed 08 April 2020, from https://www.christianpost.com/news/kenyanpastor-bans-female-congregants-from-wearing-underwear-in-church.html.

Wells, D.F., 1993, No place for truth: Or whatever happened to Evangelical theology?, W.B. Eerdmans, Grand Rapids, MI. 